\title{
Production of monoclonal antibodies to islet cell surface antigens using hybridization of spleen lymphocytes from non-obese diabetic mice
}

\author{
K. Yokono, K. Shii, J. Hari, S. Yaso, Y. Imamura, K. Ejiri, K. Ishihara, S. Fujii, T. Kazumi, H. Taniguchi and S. Baba \\ Second Department of Internal Medicine, Kobe University School of Medicine, Kobe, Hyogo, Japan
}

\begin{abstract}
Summary. Non-obese diabetic mice display a syndrome with dramatic clinical and pathological features similar to those of Type 1 (insulin-dependent) diabetes in man. Circulating autoantibodies to the surface of islet cells were demonstrated in some of these mice by a protein A radioligand assay. To produce monoclonal antibodies to islet cell surface antigens, therefore, we took the spleens of non-obese diabetic mice, transferred the spleen cells into non-immunized recipient mice, which were made immunologically incompetent by a large dose of $\mathrm{X}$-irradiation, and then fused their lymphocytes with FO mouse myeloma cells. After screening the resultant hybrids, one stable hybridoma (3A4) that produced a monoclonal antibody (IgG1) specifically bound to the surface of islet cells was obtained. The purified monoclonal antibody was bound to the surface of transplantable Syrian golden hamster insulinoma cells sevenfold more than control antibody. Adsorption of the antibody on mouse spleen lymphocytes or
\end{abstract}

thymocytes resulted in only a slight decrease in ${ }^{125}$ I-protein A binding to insulinoma cells. This antibody also reacted with the surface of mouse and rat islet cells, but not with that of rat spleen cells or hepatocytes. A spectrophotometric assay for peroxidase activity demonstrated that six times more peroxidase bound to insulinoma cells incubated with the antibody than to cells treated with control antibody. Furthermore, this antibody could be visually detected in the immunoenzymatic labelling of the surface of insulinoma cells. In summary, we have developed a novel method of producing monoclonal antibodies to the surface of islet cells for probing into the pathogenesis of Type 1 diabetes.

Key words: Type 1 diabetes, autoimmunity, islet cell surface antibodies, non-obese diabetic mice, cell fusion, monoclonal antibodies, protein A radioassay, insulinoma cells.
The development of Type 1 diabetes often follows pathological processes that result in the destruction of the pancreatic B cells. Although its pathogenetic mechanism is not understood, the demonstration of insulitis, $[1,2]$ and autoantibodies specific for pancreatic islet cells [3-5], has led to increased interest in possible autoimmune participation in Type 1 diabetes. The role of islet cell surface antibodies (ICSA) in the destruction of the pancreatic islets remains to be clarified. However, ICSA appear to be an important tool for elucidating the mechanism of both the aetiology and mechanisms of Type 1 diabetes. Studies defining the significance of ICSA have been relatively few because of the limited availability of the antibody. Eisenbarth et al., however, have reported the production of monoclonal antibodies that bind to surface antigens of islet cells by using mice immunized with intact cultured rat islet cells [6].

The study of animals displaying a spontaneous diabetic syndrome has contributed significantly to the understanding of Type 1 diabetes in man. However, to date, most such animals have corresponded more to Type 2 (non-insulin-dependent) diabetes, demonstrating obesity as well as hyperglycaemia. Recently, nonobese diabetic (NOD) mice were established by Makino et al. in Japan. In 1974, a female mouse spontaneously exhibiting glycosuria accompanied with rapid weight loss was discovered in the CTS strain which was characterized by cataractous eyes and derived from ICR mice. After more than 20 generation of sisterbrother mating, NOD mice were established in 1980 [7, 8]. NOD mice as well as BB Wistar rats [9] display a syndrome with dramatic clinical and pathological features similar to those of Type 1 diabetes in man. Since NOD mice suffer from severe insulitis for long periods [7], circulating ICSA may be demonstrated in the serum of these mice.

In the present study, we have developed a method of producing monoclonal antibodies to islet cell surface antigens using ICSA-positive NOD mice. 


\section{Materials and methods}

\section{Animals}

Female NOD mice (aged 22-28 weeks) were supplied by the Shionogi Research Laboratory, Osaka, Japan, and fed standard mouse chow and water ad libitum. Female ICR mice, female BALB/c mice and male Wistar rats were purchased from Clea, Osaka, Japan. Diabetic NOD mice were selected by testing for glycosuria with Tes-Tape (Shionogi Pharmaceuticals, Osaka, Japan). Blood samples were taken from the retro-orbital sinus and the serum was heat-inactivated at $56^{\circ} \mathrm{C}$ for $30 \mathrm{~min}$.

\section{Cells}

FO cells are azaguanine-resistant BALB/c mouse myeloma, which were developed by de St. Groth and Scheidegger [10] and were supplied by Dr. R. A. Roth, Mount Zion Hospital and Medical Center, San Francisco, California, USA. Cultured insulinoma cells (In-111) are derived from the transplantable Syrian golden hamster insulinoma [11] and were supplied by Dr. S. Uchida, Department of Viral Infection, Institute of Medical Science, University of Tokyo, Japan. Cell lines were cultured in RPMI 1640 medium containing 10\% heat-inactivated fetal calf serum and supplemented with glutamine $(1 \mathrm{mmol} / \mathrm{l})$, sodium pyruvate $(2 \mathrm{mmol} / 1)$, penicillin $(50 \mathrm{U} / \mathrm{ml})$, streptomycin $(50 \mu \mathrm{g} / \mathrm{ml})$ and 2-mercaptoethanol $(50 \mu \mathrm{mol} / 1$, Wako Pure Chemical Industries, Osaka, Japan). Serum and other supplements were obtained from Flow Laboratories, McLean, Virginia, USA. Normal mouse and rat islet cells were isolated by standard procedures [12, 13] with minor modifications. Briefly, pancreas from ICR mice or Wistar rats were digested with collagenase (Boehringer Mannheim, Mannheim, FRG), and the islets were dissociated into single cells by incubation with RPMI 1640 medium with $10 \mathrm{mmol} / 1$ Hepes containing $1 \%$ bovine serum albumin (BSA), $2 \mathrm{mmol} / 1$ EDTA and $100 \mathrm{U} / \mathrm{ml}$ dispase (bacterial neutral protease from Bacillus polymyxa, Godo Shusei, Tokyo, Japan) [14] for $30 \mathrm{~min}$ at $24^{\circ} \mathrm{C}$. The islet cells were cultured in RPMI 1640 medium with $10 \%$ fetal calf serum at $37^{\circ} \mathrm{C}$ overnight. Spleen lymphocytes and thymocytes from NOD or ICR mice were prepared by chopping with fine scissors, and the cells were suspended in RPMI 1640 medium. Rat hepatocytes were isolated by the method of Seglen [15].

\section{Hybridoma production}

The method used involved the transfer of spleen lymphocytes from donor NOD mice into non-immunized recipient ICR mice which were made immunologically incompetent by a large dose of X-rays [16]. Ten female ICR mice used as recipients were exposed to total body X-irradiation of 600 rads 8 days before cell fusion. Four hours after irradiation, $5-8 \times 10^{7}$ spleen lymphocytes obtained from each of 10 NOD non-diabetic mice were injected into the tail vein of each of the 10 irradiated ICR mice. On the day before fusion, the serum of each irradiated mouse was tested for its ability to bind to the surface of In-111 cells as described below, and one mouse was selected for the cell fusion.

On the day of the fusion, the spleen lymphocytes from this mouse were fused to FO myeloma cells using polyethylene glycol 4000 (Sigma Chemicals, St. Louis, Missouri) according to the method of de St. Groth and Scheidegger [10]. The products of the fusion were aliquoted into 10,24 -well culture plates at $2 \times 10^{5}$ spleen cells, $2 \times 10^{5} \mathrm{FO}$ cells and $2 \times 10^{4}$ mouse macrophages per well. When the hybrid cells were grown and semi-confluent, the medium was removed and assayed for antibody reacting with the surface of In-111 cells. Cells from the positive wells were cloned by limiting dilution and grown by mass culture or as ascites tumours in BALB/c mice primed with pristane (Aldrich Chemicals, Milwaukee, Wisconsin). The monoclonal antibodies from the positive hybrids were purified on a protein A-Sepharose column (Pharmacia Fine Chemicals, Piscataway, New Jersey) [17], and their immunoglobulin classes were identified by the use of rabbit anti-mouse immunoglobulins (Miles Laboratories, Elkhart, Indiana) in Ouchterlony double immunodiffusion. Protein concentrations of purified monoclonal antibodies were measured by the method of Lowry et al. [1.8], using BSA as standard.

\section{Protein $A$ radioligand assay}

Islet cell surface bound antibodies were determined by an ${ }^{125}$ I-protein A assay as described by Lernmark et al. [19]. Briefly, various living cells in RPMI 1640 with $2 \%$ BSA were incubated first with mouse serum at 1:10 dilution and supernatant of hybridomas or various concentrations of purified antibodies for $30 \mathrm{~min}$ at $24^{\circ} \mathrm{C}$. After washing four times by centrifugation, the cell pellets were incubated with ${ }^{125} \mathrm{I}$ protein A $\left(0.7-1.4 \times 10^{5} \mathrm{cpm} /\right.$ tube, New England Nuclear, Boston, Massachusetts; spec act: $90-95 \mathrm{Ci} / \mathrm{g}$ ) for $30 \mathrm{~min}$ at $24^{\circ} \mathrm{C}$. The cells were washed four times with $2 \%$ BSA in RPMI 1640 , and finally the radioactivity in the cell pellets was counted in a gamma counter (Aloka, Tokyo, Japan)

For the adsorption of purified monoclonal antibody, aliquots of antibody were resuspended with various cell numbers of mouse spleen lymphocytes, thymocytes or islet cells and incubated for $16 \mathrm{~h}$ at $4^{\circ} \mathrm{C}$. To equalize the influence of collagenase and dispase on cell membrances, spleen lymphocytes and thymocytes also were exposed to these enzymes during their isolation. The antibody was retrieved by centrifugation ( $10000 \mathrm{~g}$ for $5 \mathrm{~min}$ ) and tested for the ability to react with the surface of In-111 cells as described above.

\section{Immunoenzymatic labelling of islet cell surface antigens on In-111 cells}

Various concentrations of purified antibody or normal mouse IgG (Sigma), which served as control, were added to In-111 cells $\left(2 \times 10^{6}\right.$ cells $/ \mathrm{ml}$ ) and incubated for $30 \mathrm{~min}$ at $24^{\circ} \mathrm{C}$. After incubation, the cell suspension was centrifuged at $50 \mathrm{~g}$ for $10 \mathrm{~min}$, and the cell pellets were washed twice with $10 \mathrm{mmol} / 1$ phosphate buffered saline (PBS, $\mathrm{pH}$ 7.4) and resuspended in galactosidase-linked goat anti-mouse immunoglobulin (BRL, Gaithersburg, Maryland) at a final dilution of $1: 200$ in PBS with $1 \%$ BSA. After incubation for $60 \mathrm{~min}$ at $24^{\circ} \mathrm{C}$, the cells were centrifuged and washed as described above. The cell pellets were resuspended in buffer containing $3 \mathrm{mmol} / 1$ o-nitrophenyl- $\beta$-Dgalactopyranoside (Sigma), a chromogenic substrate for galactosidase, and $0.18 \mathrm{mmol} / 1$ mercaptoethanol [20]. The enzymic reaction was allowed to proceed for $20 \mathrm{~min}$ at $24^{\circ} \mathrm{C}$ and then was stopped by cooling the reaction tubes at $4^{\circ} \mathrm{C}$ and centrifuging the cells. $\mathrm{Na}_{2} \mathrm{CO}_{3}$ $(0.15 \mathrm{~mol} / 1)$ was added to the supernatant, and the absorbance was read at $420 \mathrm{~nm}$.

\section{Staining of In-111 cells labelled with peroxidase-linked antiglobulin}

To visualize the monoclonal antibody bound to the surface of In-111 cells, a histochemical staining for peroxidase activity was utilized [21]. In-111 cells $\left(5 \times 10^{5}\right.$ cells $\left./ 50 \mu \mathrm{l}\right)$ were incubated with $5 \mu \mathrm{g}$ of purified monoclonal antibody or normal mouse IgG for $30 \mathrm{~min}$ at $4^{\circ} \mathrm{C}$. After the cells were washed, peroxidase-linked rabbit anti-mouse $\mathrm{IgG}$ (Dako, Denmark) diluted at 1:2 was added to the cells and incubated for $15 \mathrm{~min}$ at $4^{\circ} \mathrm{C}$. After washing four times, the cells were resuspended in $15 \mathrm{mmol} / 1$ Hepes ( $\mathrm{pH} 7.4$ ) containing $0.15 \mathrm{~mol} / \mathrm{l} \mathrm{NaCl}, 5 \mathrm{mmol} / \mathrm{K} \mathrm{KCl}$ and $1 \mathrm{mg} / \mathrm{ml}$ gelatin, and the cell suspensions were applied to a microscope slide precoated with poly-L-lysine (Sigma). After removal of the unbound cells, a solution containing $1.4 \mathrm{mmol} / 13,3^{\prime}$-diaminobenzidine tetrahydrochloride (Aldrich) and $0.12 \mu \mathrm{l} / \mathrm{ml} \mathrm{H}_{2} \mathrm{O}_{2}$ was added and left for $10 \mathrm{~min}$ at $24^{\circ} \mathrm{C}$. After the cells were washed five times, $2 \% \mathrm{OsO}_{4}$ (Sigma) was added, and the cells were incubated in the dark for $20 \mathrm{~min}$ at $4^{\circ} \mathrm{C}$. The cells were washed and fixed with $0.025 \%$ glutaraldehyde in $50 \%$ glycerin and examined under a light microscope. 
Table 1. Binding of mouse serum to In -111 cells by protein A radioligand assay

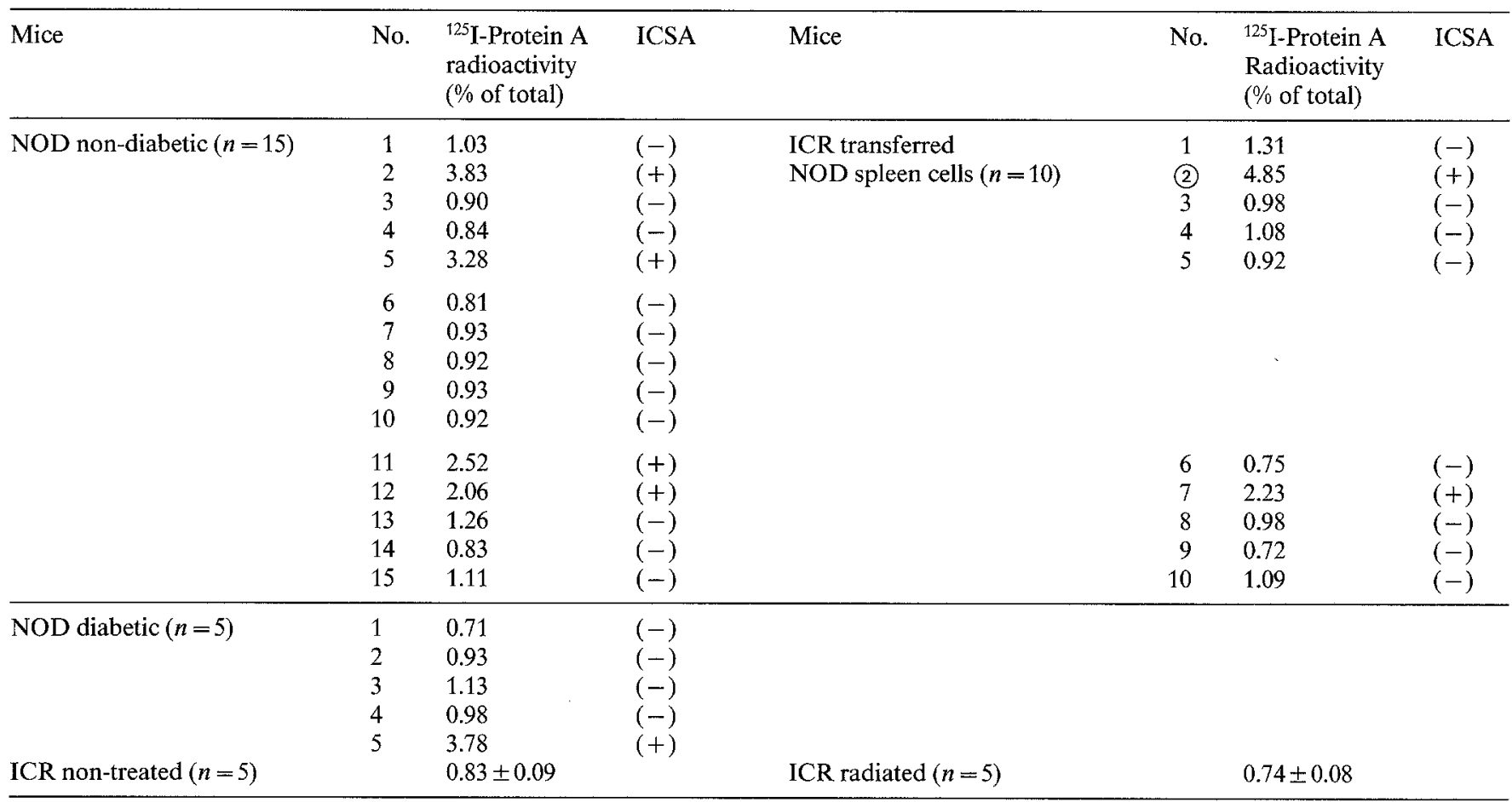

Values for ICR non-treated mice are expressed as mean \pm SD. ${ }^{125}$ I-protein A $\left(1-1.4 \times 10^{5} \mathrm{cpm}\right)$ was added to $2 \times 10^{5}$ In- 111 cells that had been preincubated with a 1:10 dilution of mouse serum. Results are expressed as the percentage bound of total radioactivity. Bound radioactivity exceeding twofold the mean control value defined ICSA-positive serum

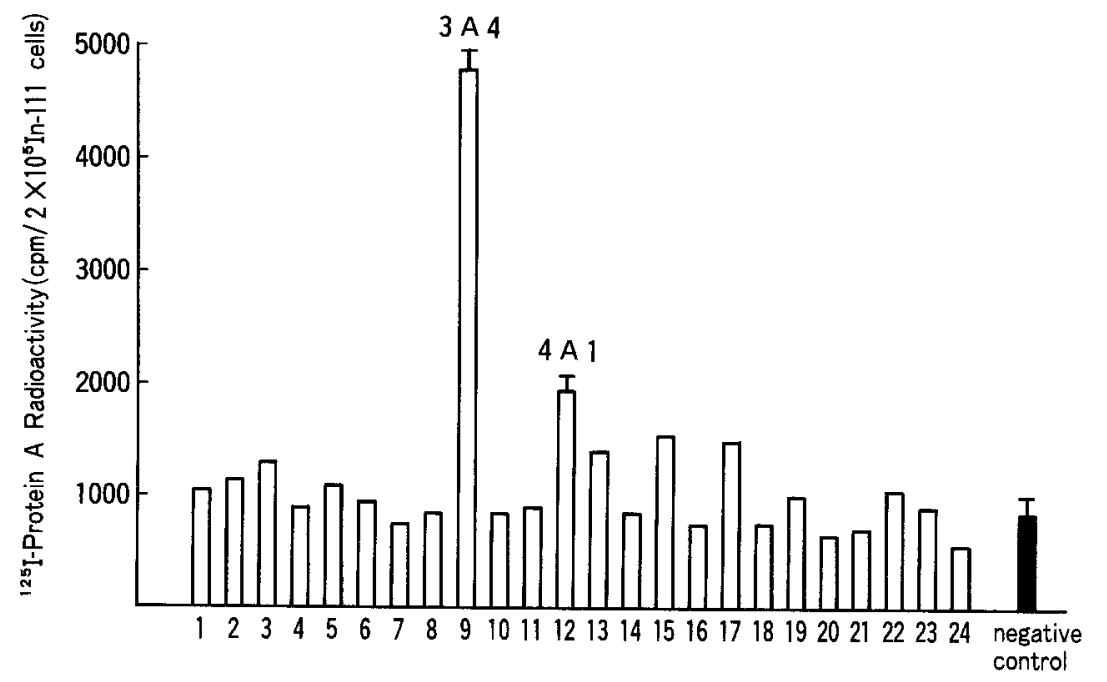

No. of Hybridomas
Fig. 1. Screening of hybridomas by the protein A radioligand assay. The binding of supernatants to $2 \times 10^{5}$ In- 111 cells was measured with ${ }^{125} \mathrm{I}$-protein A $\left(1 \times 10^{5} \mathrm{cpm}\right)$. Results from positive hybridomas and negative controls are expressed as mean $+\mathrm{SD}$ of triplicate determinations. A representative experiment of the three experiments performed is shown

\section{Results}

\section{Hybridoma production}

Twenty female NOD mice (aged 22-28 weeks) were divided into 15 non-diabetic and five diabetic mice by testing for the presence of glycosuria. Sera from these mice were evaluated for the presence of ICSA by the protein A radioligand assay. In four of the 15 non-diabetic and one of the five diabetic mice, the binding of ${ }^{125}$ I-protein A to In-111 cells exceeded the mean of that in non-treated ICR mice twofold $(0.83 \pm 0.09 \%$; Table 1). Eight days before fusion, each of the 10 spleens obtained from 10 non-diabetic NOD mice (nos.1-5 and 11-15) was transferred into each of the 10 recipient ICR mice (nos. 1-10), which had previously been exposed to X-irradiation. On the day before fusion, two transferred mice (nos. 2 and 7) showed more than double the values of ${ }^{125} \mathrm{I}$-protein A radioactivity of the ICR irradiated control mice $(0.74 \pm 0.08 \%)$. In transferred mice (nos. 5 and 6 ), which received spleen lymphocytes from ICSA-positive NOD mice (nos. 5 and 


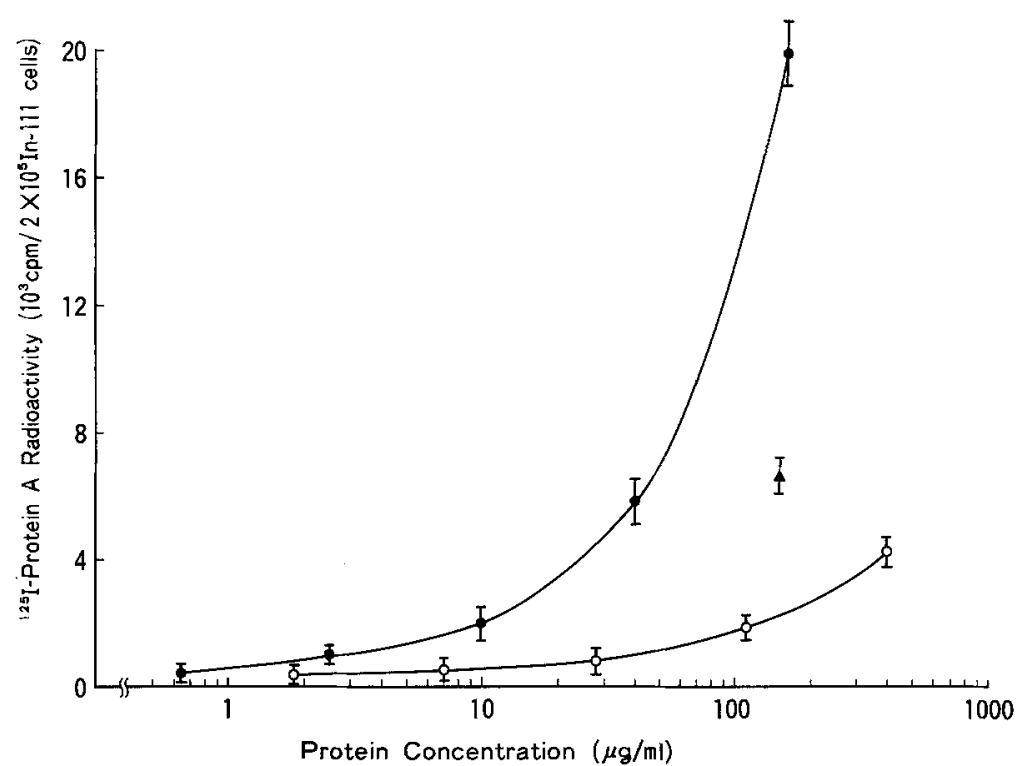

Fig. 2. Binding of purified monoclonal antibodies to In-111 cells by the protein A radioligand assay. In-111 cells $\left(2 \times 10^{5}\right)$ were first incubated with the indicated amounts of either $3 \mathrm{~A} 4(\bullet), 4 \mathrm{~A} 1(\boldsymbol{\Delta})$ or normal mouse IgG $(0)$ and the binding assayed with ${ }^{125} \mathrm{I}$-protein $\mathrm{A}\left(1.2 \times 10^{5} \mathrm{cpm}\right)$. Results are expressed as mean \pm SD of three different experiments

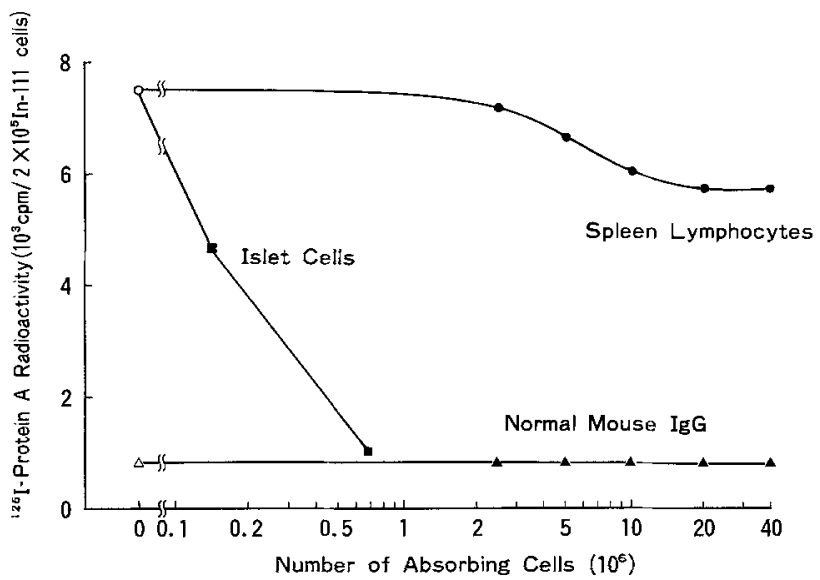

Fig.3. Quantitative adsorption of purified monoclonal antibody $3 \mathrm{~A} 4$ with mouse spleen lymphocytes and islet cells. $3 \mathrm{~A} 4(100 \mu \mathrm{g} / \mathrm{ml})$ was adsorbed with the indicated cell numbers of either spleen cells $(-)$ or islet cells ( $)$ and the binding of adsorbed antibody to $2 \times 10^{5} \mathrm{In}-111$ cells was estimated with ${ }^{125}$ I-protein $\mathrm{A}\left(0.7 \times 10^{5} \mathrm{cpm}\right)$. The bindings of ${ }^{125} \mathrm{I}$-protein $\mathrm{A}$ to In-111 cells after incubation with unabsorbed antibody $(O)$ or with normal mouse $\operatorname{IgG}(100 \mu \mathrm{g} / \mathrm{ml})(\Delta)$ and of mouse $\operatorname{IgG}$ adsorbed with spleen lymphocytes $(\boldsymbol{\Delta})$ are shown also. Results are the mean values of two or three different experiments

11), however, the binding of ${ }^{125} \mathrm{I}$-protein $\mathrm{A}$ to $\mathrm{In}-111$ cells showed normal values in samples taken 7 days after the transfer of spleen lymphocytes. Since the radioactivity in transferred mouse no. 2 was nearly seven times higher than that in irradiated control mice, we chose this mouse for the cell fusion. Fourteen days after fusion, 24 of the 240 culture wells showed growth of hybridomas. The results of a screening assay by ${ }^{125} \mathrm{I}-$ protein A binding to In-111 cells are shown in Figure 1. Significant antibody binding, which was more than twice the mean of binding with negative control FO supernatant $\left(838 \pm 75 \mathrm{cpm} / 2 \times 10^{5}\right.$ cells), was found in only two hybridomas $(3 \mathrm{~A} 4 ; 4796 \pm 98 \mathrm{cpm}$ and $4 \mathrm{~A} 1$; $1962 \pm 67 \mathrm{cpm})$. These two hybridomas were grown in the mass culture and as ascites tumours, and the monoclonal antibodies were purified by protein A-Sepharose. Both antibodies were identified as an IgG1 by Ouchterlony double immunodiffusion. Monoclonal antibody purified from $3 \mathrm{~A} 4$ has been mainly used for further investigations.

\section{Binding of ${ }^{125}$ I-protein $A$}

Serial dilutions of purified antibody $3 \mathrm{~A} 4$ were incubated with In-111 cells and the binding of antibody detected with ${ }^{125}$ I-protein $\mathrm{A}$. The binding of antibody to In-111 cells was increased in proportion to increasing concentrations of antibody, and the binding of ${ }^{125} \mathrm{I}$-protein A to In- 111 cells incubated with $100 \mu \mathrm{g} / \mathrm{ml}$ of antibody $3 \mathrm{~A} 4$ was sevenfold that of the cells incubated with the same amount of normal mouse IgG. Purified antibody 4A1 was bound about threefold more than control IgG to In-111 cells (Fig. 2).

Adsorption of the purified antibody $3 \mathrm{~A} 4$ to mouse spleen or islet cells is shown in Figure 3. The adsorption curve for spleen lymphocytes declined gradually and reached an apparent maximum with $2 \times 10^{7}$ cells. On the other hand, ${ }^{125}$ I-protein A binding to In-111 cells decreased from $7.5 \%$ to $1.2 \%$ (almost the same percentage as that shown for the non-specific binding of normal mouse IgG) by the adsorption of $3 \mathrm{~A} 4$ to mouse islet cells at $7 \times 10^{5}$ cells.

The effect of mouse thymocytes at concentrations of $1.5-25 \times 10^{6}$ cells on the adsorption of $3 \mathrm{~A} 4$ was similar to that of spleen lymphocytes (data not shown). Direct binding of $3 \mathrm{~A} 4$ to various living cells is shown in Figure 4 . The binding of ${ }^{125}$ I-protein A to In- 111 cells incubated with $100 \mu \mathrm{g} / \mathrm{ml}$ of antibody $3 \mathrm{~A} 4$ was $19331 \pm$ $1582 \mathrm{cpm} / 2 \times 10^{5}$ cells compared with $1565 \pm$ $203 \mathrm{cpm} / 2 \times 10^{5}$ cells when incubated with $100 \mu \mathrm{g} / \mathrm{ml}$ of normal mouse IgG. At the same concentrations of $3 \mathrm{~A} 4$ and normal mouse $\mathrm{IgG}$, the binding to mouse and 


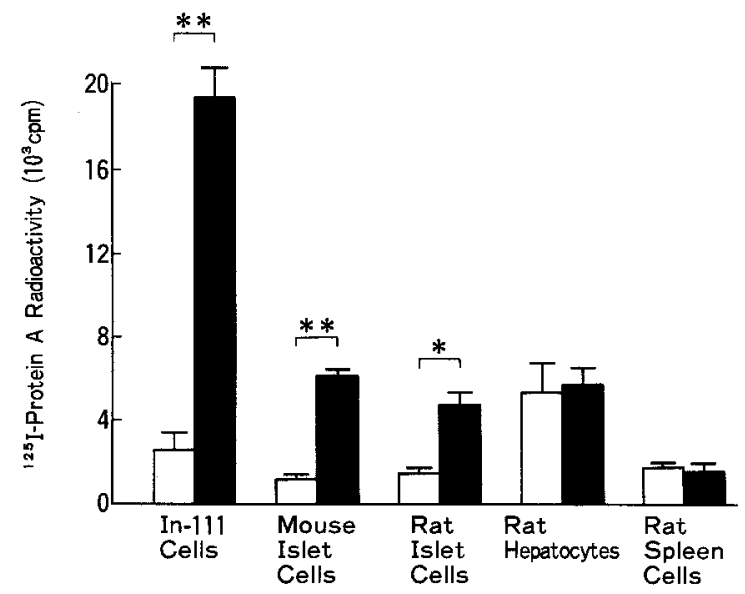

Fig.4. Binding of purified monoclonal antibody $3 \mathrm{~A} 4$ to the surface of various cells by the protein $\mathrm{A}$ radioligand assay. Antibody $3 \mathrm{~A} 4$ $(100 \mu \mathrm{g} / \mathrm{ml})(\square)$ or normal mouse $\operatorname{IgG}(100 \mu \mathrm{g} / \mathrm{ml})(\square)$ was incubated with either $2 \times 10^{5} \mathrm{In}-111$ cells, $3 \times 10^{4}$ mouse islet cells, $1.5 \times 10^{4}$ rat islet cells, $2 \times 10^{5}$ rat hepatocytes or $2 \times 10^{6}$ rat spleen cells. The binding was assayed with ${ }^{125} \mathrm{I}$-protein $\mathrm{A}\left(1.2 \times 10^{5} \mathrm{cpm}\right)$ and the results are expressed as mean $+\mathrm{SD}$ of triplicate determinations. ${ }^{* *} \mathrm{p}<0.001$, ${ }^{*} \mathrm{p}<0.01$

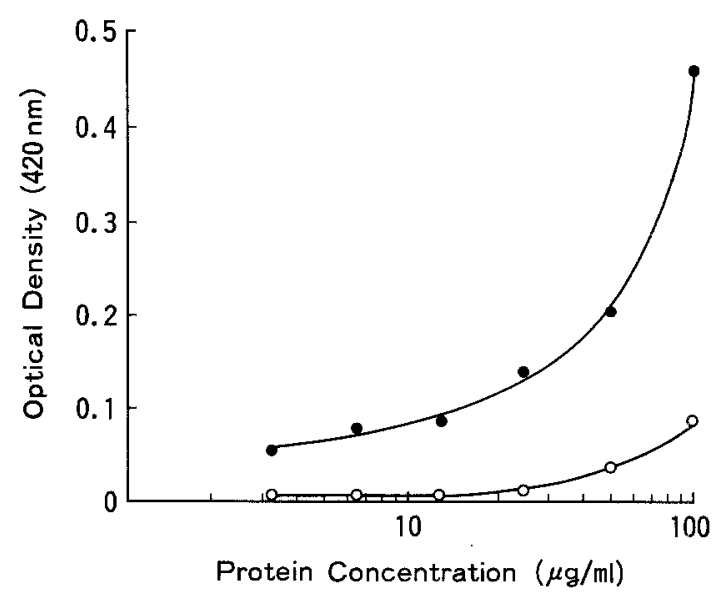

Fig.5. Immunoenzymatic labelling of In-111 cells with purified monoclonal antibody $3 \mathrm{A4}$. In-111 cells were incubated with the indicated amounts of either $3 \mathrm{~A} 4(-)$ or normal mouse $\operatorname{IgG}(\mathrm{O})$ and then with a galactosidase-linked second antibody, and assayed spectrophotometrically. One experiment representative of three is shown

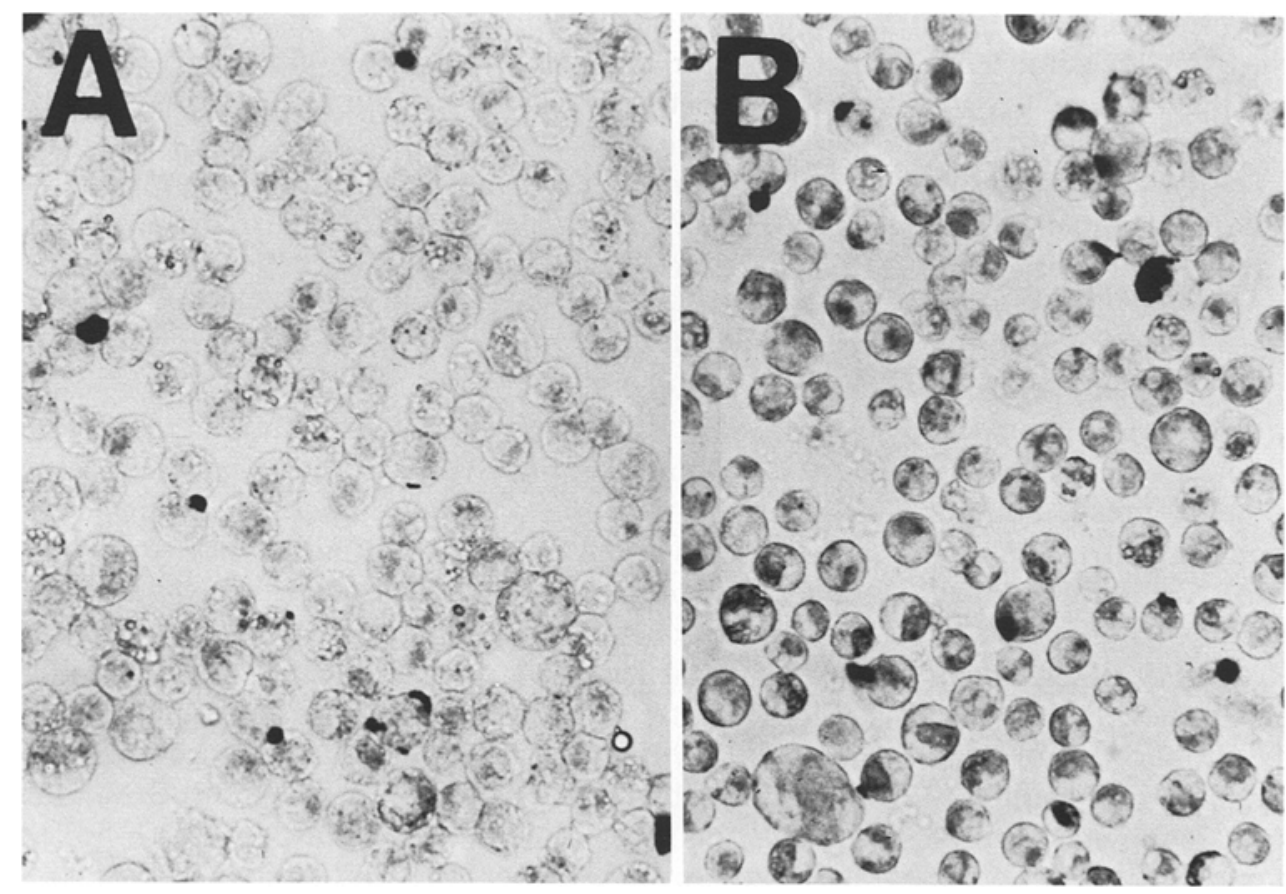

Fig. 6. Visual detection of islet cell surface antigens on In-111 cells. In-111 cells were incubated with either normal mouse $\operatorname{IgG}(\mathrm{A})$ or purified antibody $3 \mathrm{~A} 4$ (B) and treated with a peroxidase-linked second antibody and 3,3'-diamino-benzidine tetrahydrochloride. One experiment representative of four is shown rat islet cells incubated with $3 \mathrm{~A} 4$ was $6089 \pm$ $146 \mathrm{cpm} / 3 \times 10^{4}$ cells and $4780 \pm 611 \mathrm{cpm} / 1.5 \times 10^{4}$ cells compared with $1178 \pm 110 \mathrm{cpm} / 3 \times 10^{4}$ cells and $1563 \pm 203 \mathrm{cpm} / 1.5 \times 10^{4}$ cells incubated with control mouse $\mathrm{IgG}$, respectively. However, the binding to rat hepatocytes $\left(2 \times 10^{5}\right)$ and spleen cells $\left(2 \times 10^{6}\right)$ showed no significant difference between $3 \mathrm{~A} 4$ and normal mouse IgG.

\section{Immunoenzymatic labelling of surface of In-111 cells}

Either purified monoclonal antibody $3 \mathrm{~A} 4$ or normal mouse IgG was incubated with In-111 cells and binding to the cells was quantified using a second antibody coupled to galactosidase. With increasing quantities of antibody $3 \mathrm{~A} 4$, increased galactosidase activity was bound to the cells (Fig. 5). In-111 cells incubated with $100 \mu \mathrm{g} /$ $\mathrm{ml}$ of antibody $3 \mathrm{~A} 4 \mathrm{had}$ sixfold more galactosidase activity than cells incubated with the same amount of normal mouse IgG.

To visualize the binding of antibody to the surface of In-111 cells, the histochemical stain for peroxidase activity, 3,3'-diamino-benzidine tetrahydrochloride, was utilized. In-111 cells treated first with normal mouse IgG showed no apparent staining. In contrast, cell sus- 
pensions treated with antibody $3 \mathrm{~A} 4$ contained many stained cells that had a black ring around the cell periphery (Fig. 6).

\section{Discussion}

The present study demonstrates that the production of monoclonal antibodies reacting with the surface of islet cells is successfully achieved when spleen cells of NOD mice are fused with FO myeloma cells. Based on the data in Table 1 it was assumed that the production of autoantibodies to islet cells in NOD mice was present before diagnosis and in fact may be diminished at the time of overt diabetes. Therefore, we selected non-diabetic NOD mice for the production of monoclonal antibodies to islet cell surface antigens. In preliminary experiments, we took the spleens of NOD mice and fused their lymphocytes directly with FO myeloma cells. However, we were unable to obtain hybridoma production from four such fusions. It is difficult to explain why these direct fusions were unsuccessful. We could not produce hybridomas by the fusion of spleen cells from non-immunized mice and FO cells using the same technique as described here, whereas high frequencies of hybridomas were obtained when spleen cells from mice immunized with sheep red blood cells were used (unpublished data). Several lines of indirect evidence suggest that activated B cells fuse preferentially with myeloma cells, or at least result in a higher frequency of viable hybridomas [22]. Mosmann et al. also reported that the total number of hybridomas obtained, using spleen cells from non-immunized mice, was higher after stimulation of spleen cells with lipopolysaccharide and lipopolysaccharide stimulation could increase the frequency of antigen-specific hybridomas from immunized mice [23]. Since preliminary fusions employed spleen lymphocytes from autoimmune mice that were not pre-immunized with antigens, there must have been low numbers of blast lymphocytes in these spleen cells.

Thus, the spleen cells from NOD mice were transferred into heavily irradiated ICR mice. This method is based on the fact that the intravenous injection of spleen cells into isologous hosts previously exposed to total-body irradiation leads to the formation of colonies of proliferating cells in the spleens of these animals [24]. We could actually observe whitish multiple colonies in the spleens of ICR mice with transferred spleen cells from NOD mice. Under these conditions, the antibody formed in the recipient is derived from donor-primed cells alone, and not from the recipient [16]. As shown in Table 1, ICSA was demonstrated in two of four ICR mice with transferred spleen cells from ICSA-positive NOD mice at 7 days after transfusion. The results of fusion using such an in vivo culture technique showed that the frequency of hybridomas was considerably lower than that reported for other conventional fusions $[6,25,26]$. These results appear to be due to employing spleen cells from non-immunized mice for cell fusion, because high frequencies of specific hybridomas are dependent on the increased frequency of specific B-blast cells at the time of fusion these being obtained by frequent immunization with high doses of antigens [23,27]. Therefore, high frequencies of antigen-specific hybridomas are expected by fusing in vitro lipopolysaccharide-stimulated spleen cells from ICSA-positive NOD mice with myeloma cells and this fusion procedure is now in progress.

Five different experimental approaches indicated that the monoclonal antibody 3A4 was specifically bound to the surface of islet cells. Firstly, purified antibody $3 \mathrm{~A} 4$ was bound to the surface of cultured cells of transplantable Syrian golden hamster insulinoma, In-111, sevenfold more than control antibody, using the protein A radioligand assay. Secondly, the binding of ${ }^{125}$ I-protein A to In-111 cells was significantly reduced by adsorption of antibody $3 \mathrm{~A} 4$ to $7 \times 10^{5}$ mouse islet cells, whereas adsorption of $3 \mathrm{~A} 4$ to as many as $4 \times 10^{7}$ mouse spleen lymphocytes only slightly decreased the binding of ${ }^{125}$ I-protein A to In-111 cells. Because both insulin and glucagon are secreted by In-111 cells and their insulin content is almost the same as that of normal hamster pancreas, it is assumed that In-111 cells comprise at least A and B cells [28]. Our result also indicates that In-111 cells may express a large number of surface antigens, including tumour-specific antigens, but share the surface antigens of normal pancreatic islet cells and thus are useful for detecting ICSA. Thirdly, this antibody also reacted with the surface of mouse and rat islet cells, but not with that of rat hepatocytes or spleen cells. Although ${ }^{125}$ I-protein A binding to rat hepatocytes showed a high value, indicating non-specific binding or trapping of immunoglobulin to the cells, these results suggest that this antibody binds to the surface of various species of islet cells. Fourthly, a spectrophotometric assay for galactosidase activity demonstrated that galactosidase bound to In-111 cells incubated with antibody $3 \mathrm{~A} 4$ six times more than to cells incubated with control antibody. And fifthly, antibody $3 \mathrm{~A} 4$ could be visually detected on the surface of the In-111 cells after incubation with a peroxidase-linked antibody directed against the first antibody and histochemical staining for peroxidase activity.

In summary, we have obtained hybridomas that produce monoclonal antibodies to the surface of islet cells by using hybridization of spleen lymphocytes from nonimmunized NOD mice. Since antibody $3 \mathrm{~A} 4$ specifically binds to islet cell surface antigens, this antibody provides a useful tool for studies on purification of antigens and for clarification of the pathogenesis of Type 1 diabetes. Finally, the method described here should be applicable to other autoimmune disorders to produce monoclonal antibodies against the autoantigens.

Acknowledgements. The authors wish to thank Drs. Y.Tochino and S. Makino, Shionogi Research Laboratory for their generously supply of non-obese diabetic mice, Dr. S.Uchida, Institute of Medical 
Science, University of Tokyo and Dr. S. Kawazu, Fourth Department of Internal Medicine, Saitama Medical School for In-111 cells, and Dr. R. A. Roth, Mount Zion Hospital and Medical Center, Department of Physiology, University of California, San Francisco for a critical reading of the manuscript.

\section{References}

1. Gepts W (1965) Pathologic anatomy of the pancreas in juvenile onset diabetes. Diabetes 14: 619-639

2. Gepts W, Le Compte PM (1981) The pancreatic islets in diabetes. Am J Med 70: 105-115

3. Bottazzo GF, Florin-Christensen A, Doniach D (1974) Islet cell antibodies in diabetes mellitus with autoimmune polyendocrine deficiencies. Lancet 2: 1279-1283

4. MacCuish AC, Jordan J, Campbell CJ, Duncan LJP, Irvine WJ (1974) Antibodies to islet-cells in insulin-dependent diabetics with coexistent autoimmune disease. Lancet $2: 1529-1533$

5. Lernmark $\AA$, Freedman ZP, Hoffmann C, Rubenstein AH, Steiner DF, Jackson RJ, Traisman HS (1978) Islet cell surface antibodies in juvenile diabetes mellitus. N Engl J Med 299: 375-380

6. Eisenbarth GS, Oie H, Gazdar A, Chick W, Schultz JA, Scearce RM (1981) Production of monoclonal antibodies reacting with rat islet cell membrane antigens. Diabetes 30: 226-230

7. Makino S, Kunimoto K, Muraoka Y, Mizushima Y, Katagiri K, Tochino Y (1980) Breeding of a non-obese diabetic strain of mice. Exp Anim 29:1-13

8. Makino S, Kunimoto K, Muraoka Y, Katagiri K (1980) Effect of castration on the appearance of diabetes in the NOD mouse. Exp Anim 30: 137-140

9. Nakhooda AF, Like AA, Chappel CL, Murray FT, Marliss EB (1977) The spontaneously diabetic Wistar rat. Metabolic and morphologic studies. Diabetes 26: 100-112

10. Fazekas de St. Groth S, Scheidegger D (1980) Production of monoclonal antibodies. Strategy and tactics. J Immunol Methods 35: $1-21$

11. Uchida S, Watanabe S, Aizawa T, Furuno A, Muto T (1979) Polyoncogenicity and insulinoma inducing ability of BK virus, a human papovavirus, in Syrian golden hamsters. J Natl Cancer Inst 63: $119-126$

12. Lernmark $\AA$ (1974) The preparation of and studies on free cell suspensions from mouse pancreatic islets. Diabetologia 10: 431-438

13. Dobersen M, Scharff J, Notkins A (1980) Microculture system for studying monolayers of functional B-cells. Endocrinology 106: 1070-1073

14. Matsumura T, Nitta K, Yoshikawa $M$, Takaoka $T$, Katsuta $H$ (1975) Action of bacterial neutral protease on the dispersion of mammalian cells in tissue culture. Jpn J Exp Med 45: 383-392

15. Seglen PO (1973) Preparation of rat liver cells. III. Enzymatic requirements for tissue dispersion. Exptl Cell Res 82: 391-398

16. Hamaoka T, Kitagawa M, Matsuoka Y, Yamamura Y (1969) An- tibody production in mice. I. The analysis of immunological memory. Immunology 17: 55-69

17. Oi VT, Herzenberg LA (1980) Immunoglobulin-producing hybrid cell lines. In: Mishell BB, Shiigi SM (eds) Selected methods in cellular immunology, Vol 17. Freeman, San Francisco, pp 351-372

18. Lowry HO, Rosebrough NJ, Farr AL, Randall RJ (1951) Protein measurement with the Folin phenol reagent. J Biol Chem 53: 265-275

19. Lernmark Å, Kanatsuna T, Patzelt C, Diakoumis K, Carroll R, Rubenstein AH, Steiner DF (1980) Antibodies directed against the pancreatic islet cell plasma membrane. Detection and specificity. Diabetologia 19: 445-451

20. Roth RA, Rotman B (1975) Inactivation of normal $\beta$-D-galactosidase by antibodies to defective forms of the enzyme. $J$ Biol Chem 250: 7759-7765

21. Jonak ZL (1980) Peroxidase-conjugated antiglobulin method for visual detection of cell-surface antigens. In: Kennet $\mathrm{RH}$, McKearn TJ, Bechtol KB (eds) Monoclonal antibodies. Plenum Press, New York, pp 378-380

22. Köhler G, Shulman MJ (1978) Cellular and molecular restrictions of the lymphocyte fusion. Curr Top Microbiol Immunol 81: $143-148$

23. Mosmann TR, Longenecker BM (1982) The high background immune reactivity of mice to polymorphic determinants on xenogenetic erythrocytes: theoretical and practical implications. J Immunol 128: 100-104

24. Till JE, McCulloch EA (1961) A direct measurement of the radiation sensitivity of normal mouse bone marrow cells. Radiat Res 14: 213-222

25. Fraser CM, Venter JC (1980) Monoclonal antibodies to $\beta$-adrenergic receptors: Use in purification and molecular characterization of $\beta$ receptors. Proc Natl Acad Sci USA 77: 7034-7038

26. Myles DG, Primakoff P, Bellvé AR (1981) Surface domains of the guinea pig serum defined with monoclonal antibodies. Cell 23: 433-439

27. Stähli C, Staehelin T, Miggiano V, Schmidt J, Häring P (1980) High frequencies of antigen-specific hybridomas. Dependence on immunization parameters and prediction by spleen cell analysis. J Immunol Methods 32: 297-304

28. Negishi K (1983) Quantitative estimation of islet cell surface antibodies using ${ }^{125} \mathrm{I}$-antihuman IgG antibody and insulinoma cells as target cells, and its clinical application. J Japan Diab Soc 26: $485-496$

Received: 14 July 1983

and in revised form: 2 January 1984

Dr. Koich Yokono

Second Department of Internal Medicine

Kobe University School of Medicine

Kusunoki-cho, 7-chome

Chuo-ku, Kobe

Japan 